\title{
Does Government Structure Matter? A Comparative Analysis of Urban Bus Transit Efficiency
}

\author{
Suzanne Leland and Olga Smirnova \\ University of North Carolina at Charlotte
}

\begin{abstract}
As public transit becomes more and more important to our economy, it is imperative that we understand which governing system achieves optimal efficiency. Following up on the work of Perry and Babitsky (1986), we quantitatively test whether certain forms of public governance are more efficient administrators of bus service. We utilize 2004 data from the National Transit Association database and control for federal funding, whether services are contracted out, region, population density, whether the system has a fixed guideway, the presence of local dedicated funding, and the ratio of local to federal funding. We find that special-purpose governments are more likely than general-purpose governments (cities and counties) to operate more efficiently. We also discovered that governments that contract out for some or all of their bus services are also more likely to be efficient than those public agencies that directly operate all of their services.
\end{abstract}

\section{Introduction}

This research is designed to add some theoretical and empirical insight into how forms of government impact the operating efficiency of bus service. Bus service is found in every major city throughout the United States. It is a popular transit option because of its operating flexibility and ability to be constructed quickly, 
incrementally, and economically. The systems vary in usage, design, and operations. Currently, bus service is almost exclusively operated at the local level publicly, either through city or county government or via a special- purpose government developed for transit. ${ }^{1}$

Of interest to policy-makers is the question: Does form of government matter? In other words, are some types of governments more efficient than others in delivering bus service? Specifically, are special-purpose governments that perform a single function, public transit, more efficient than general-purpose governments (cities and counties) that perform multiple functions? In this article, we empirically test whether certain forms of government operate more or less efficiently while controlling for whether some or all of the functions are contracted out, the ratio of local to federal funding, whether the system contains a fixed guideway, region, existence of a dedicated form of funding, and service area density.

\section{Forms of Transit Governance}

Little research has addressed whether form of government impacts service delivery in general and transportation efficiency specifically. More than 20 years ago, Perry and Babitsky (1986) examined the organization of mass transit systems by testing the viability of particular privatization strategies for the operations of bus service. They utilized data from 1980 and 1981 reported under Section 15 of the Urban Mass Transportation Act and compared five existing organizational forms on a variety of efficiency, effectiveness, and utilization indicators. They found that publicly managed special-purpose governments (especially public authorities) stood out from other types of governments. They debunked past research findings, which they believed had overstated the relative efficiency of general-purpose governments. They argued that these systems were more efficient than other publicly owned systems in revenue generation in 1981. The purpose of our study is to follow up on Babitsky and Perry's (1986) findings to determine if, 20 years later, bus service systems are more efficient when housed in a special-purpose government than in a general-purpose government using the latest transit data (2004).

Other research on transit governance has tested the relationship between form of government and federal funding. Smirnova, Leland, and Johnson (2005) argue that institutional arrangements for transit districts make a difference in securing funds from the federal government-especially when they embark on large capital projects such as building or expanding a subway, commuter rail, or light rail system. 
Their research quantitatively tests whether certain forms of government are more conducive to receiving federal funding while controlling for mode, region, population, and key electoral swing states. Utilizing the 2002 data at the transit agency level, from across the entire universe of transit agencies in the United States, they find a relationship between federal funding and form of government. The federal government indirectly favors special-purpose governments over general-purpose governments in their allocation of transit funding. This could be in part because they are more aggressive in their requests for funds.

The search for appropriate forms of government for delivering public service has been a recurring theme within the literature of public administration and public policy. According to Perry and Babitsky (1986), early municipal reforms were motivated by the concern for eliminating corruption associated with basic urban services such as police and public sanitation. Reforms initiated in the 1960s to stem corruption emphasized decentralization of these services to improve responsiveness and accessibility (Perry and Babitsky 1986). More recent reforms have focused on privatization, especially contracting out, which is the opposite of what has occurred with public transportation. Until 1964, when federal capital subsidies were made available to local governments, increasing numbers of bus systems were acquired by public agencies (Perry and Babitsky 1986). Today, as will be discussed below, the majority of bus systems are publicly owned.

Public bus systems are typically housed either in general-purpose governments (cities or counties) or special-purpose governments. Within these two types, some systems are contracted out and operated by a private management service company. Under this classification of transit governance, a resident team of professionals provides technical support from the firm's central office and controls the day-to-day operations of the system. The contract's financial conditions are usually on a fixed-fee or percentage of gross farebox revenue basis with provisions for inflation (Perry and Babitsky 1986).

A key feature of special-purpose governments is that their jurisdictions are not confined to one city or county, and are regional in nature. They are part of what Olberding (2002) calls "targeted" regional strategies for communities facing problems that require cooperation. Such strategies have become popular in the past three decades and are not as radical or politically problematic as metropolitan governments, consolidation, or annexation (Smirnova, Leland, and Johnson 2005). The attractiveness of special-purpose governments is evidenced by their popular- 
ity. Special-purpose governments have grown from approximately 8,000 in the 1940 s to more than 35,000 today (Olberding 2002).

While special-purpose governments do have territorial boundaries, they also have a level of geographic flexibility (Hooghe and Marks 2003) that general-purpose governments do not. Special-purpose governments often overlap other governments (Burns 1994). When a special "need" arises that falls outside traditional city and county boundaries, creating a special-purpose government is one method that citizens can utilize to address it.

The definition of special-purpose governments for this research includes public authorities, government corporations, and special districts. This distinction is used by Eger (2002) to differentiate their forms. Each category is represented by the entity's ability to control the amount of information reported to the state government, its financial characteristics, and its ability to issue debt (Eger 2002). While the authority of each of these types of special-purpose governments to tax and spend varies based on state law and type of organization, they all are motivated by a single factor and driven toward a single outcome (Foster 1997). We have included several control measures to differentiate between various types.

Whereas special-purpose governments provide for greater regional cooperation, they have been criticized for devoting proportionally more resources to relatively expensive capital projects compared to a typical general-purpose government. The costs for special-purpose governments (particularly public authorities) are higher for a variety of reasons. The most common are higher service quality and limited political visibility (associated with greater freedom to implement unpopular development projects; Smirnova, Leland, and Johnson 2005). Nevertheless, they are the most popular form of local government in the United States as well as the fastest growing (Burns 1994). Conversely, general-purpose governments for the purpose of this study are defined as cities and counties that provide public transportation. Transit agencies in these systems must compete with other goods and services for revenue (Smirnova, Leland, and Johnson 2005).

The boundaries that citizens draw when they create special-purpose governments or city or county governments matter in American politics because they define the limits of particular arrangements of political power, types and levels of service delivery, characteristics of political participation and accountability, and certain arrangements for funding the work of the local government (Burns 1994). For this study, we assert that institutional arrangements for transit agencies matter, and believe that there is still support for Perry and Babitsky's findings that 
they are more efficient in delivering bus service. This research explores whether special-purpose governments are more efficient because they are better suited to address regionwide transit problems that lead to increased ridership. While a regional approach seems logical, and special districts appear to be politically feasible options, special-purpose governments face additional barriers. Unlike general-purpose governments, special-purpose governments must secure funds regionally outside traditional city and county borders. This requires horizontal intergovernmental cooperation and bargaining or contracting, which may be a disincentive for expanding into new territory if the special-purpose government requires a dedicated funding source (Smirnova, Leland, and Johnson 2005).

\section{Dataset Description and Selection Procedures}

The National Transit Database (NTD) provides an invaluable source of quantitative data on federal transit funding, efficiency measures, effectiveness measures, and forms of government for our research. The response rate to the NTD is about 100 percent. "Simply put, the universe is known" (BTS 2002). We use the latest released dataset for the 2004 fiscal year, which includes the institutional forms of transit agencies represented in Table 1. In this article, we focus only on the U.S. states and exclude territorial transit agencies such as in Puerto Rico. Also, we are interested only in the difference between special- and general-purpose governments so we exclude state-run services and privatized services from our study.

We define special-purpose governments as a single-purpose agency with either an elected or appointed board of directors. This includes public authorities and special districts. We define general-purpose governments as a unit of a city or county government. This limits our universe to 533 agencies, with a proportional sample of each type as demonstrated in Table 2. There are also two additional criteria for our sample: type of service and mode of transportation. The type of service (TOS) focuses on the agencies that directly operate (DO) or contract out (PT) for part or all of their services; thus, we eliminate unique or special service providers, such as agencies that are engaged only in planning activities. 


\section{Table 1. Transit Agencies by Institutional Agency Type}

\begin{tabular}{|l|l|l|l|}
\hline Agency Type & Total N & $\begin{array}{l}\text { Mean Service } \\
\text { Area } \\
\text { (square miles) }\end{array}$ & $\begin{array}{l}\text { Mean Service } \\
\text { Population }\end{array}$ \\
\hline $\begin{array}{l}\text { 1. Public agency or authority that directly } \\
\text { operates all transit service (not a state DOT) }\end{array}$ & 210 & 283 & 325,538 \\
\hline $\begin{array}{l}\text { 2. Public agency or authority that contracts } \\
\text { for some or all transit service (not a state } \\
\text { DOT) }\end{array}$ & 341 & 332 & 714,650 \\
\hline 3. State Department of Transportation & 5 & 1,021 & $1,854,448$ \\
\hline $\begin{array}{l}\text { 4. Private transportation provider reporting } \\
\text { on behalf of a public agency or authority } \\
\text { (not a broker) }\end{array}$ & 35 & 408 & $1,297,412$ \\
\hline $\begin{array}{l}\text { 5. Private transportation broker reporting on } \\
\text { behalf of a public agency or authority }\end{array}$ & 2 & 586 & $1,430,034$ \\
\hline 6. Other & 28 & 1,989 & $3,850,842$ \\
\hline
\end{tabular}

Source: Authors' calculations based on 2004 NTD database.

Notes: The total universe constitutes 637 transit agencies, but 16 are from Puerto Rico. Thus, total population of interest is 621 for this table.

\section{Table 2. Transit Agencies by Institutional and Organization Type}

\begin{tabular}{|c|c|c|}
\hline $\begin{array}{l}\text { Institutional } \\
\text { Type }\end{array}$ & $\begin{array}{l}\text { Directly Operates Services } \\
\text { (DO, total } N=134)\end{array}$ & $\begin{array}{l}\text { Purchased Transportation } \\
\text { (PT, total } N=173)\end{array}$ \\
\hline $\begin{array}{l}\text { General- } \\
\text { purpose } \\
\text { government } \\
\text { (total } \mathrm{N}=153 \text { ) }\end{array}$ & $\begin{array}{l}\mathrm{N}=74 \\
\text { Mean area size }=178 \\
\text { Median area size }=39 \\
\text { Mean population served }=115,771 \\
\text { Median population served }=78,585\end{array}$ & $\begin{array}{l}\mathrm{N}=79 \\
\text { Mean area size }=178 \\
\text { Median area size }=59 \\
\text { Mean population served }=361,849 \\
\text { Median population served }=170,669\end{array}$ \\
\hline $\begin{array}{l}\text { Special- } \\
\text { purpose } \\
\text { government } \\
\text { (total } \mathrm{N}=154)\end{array}$ & $\begin{array}{l}\mathrm{N}=60 \\
\text { Mean area size }=389 \\
\text { Median area } \text { size }=103 \\
\text { Mean population served }=275,154 \\
\text { Median population served }=154,601\end{array}$ & $\begin{array}{l}\mathrm{N}=94 \\
\text { Mean area size }=478 \\
\text { Median area } \text { size }=296 \\
\text { Mean population served }=1,091,351 \\
\text { Median population served }=524,725\end{array}$ \\
\hline
\end{tabular}

Source: Authors' calculations based on 2004 NTD database. $\mathrm{N}=307$.

Notes: The table excludes 63 agencies with less than 9 vehicles as well as 133 agencies that do not operate buses for mass transit (only vanpool or direct response services). 
With the second selection criteria, mode of transportation, our sample focuses on agencies that operate bus (MB) or bus and any additional mode of transportation. Thus, we exclude transit agencies that operate only vanpool or direct response services as well as agencies that provide only rail services such as the Alaskan Railroad. Vanpool services are usually very small agencies, while light rail services are operated by large agencies. We also look at fixed guideway systems (FG) for bus operations because we hypothesize that providing such services requires considerably higher operating and capital expenses. Table 3 represents a typology of transportation modes by rail/nonrail and FG/non-FG. Our additional mode of transportation variable includes all rail modes and FG rubber tire modes such as trolleybuses or aerial tramway.

\section{Table 3. Transportation Modes}

\begin{tabular}{|c|c|c|}
\hline & Rail & Nonrail \\
\hline $\begin{array}{l}\text { Fixed Guideway (FG): A } \\
\text { separate right-of-way (ROW) } \\
\text { or rail for exclusive use of } \\
\text { mass transportation or "using } \\
\text { fixed catenary system usable } \\
\text { by the other forms of } \\
\text { transportation" }\end{array}$ & $\begin{array}{l}\text { Automated Guideway (AG), } \\
\text { Cable Car (CC), Commuter } \\
\text { Rail (CR), Heavy Rail (HR), } \\
\text { Inclined Plane (IP), Light } \\
\text { Rail (LR), Monorail (MO), } \\
\text { Alaska Railroad (AR) }\end{array}$ & $\begin{array}{l}\text { Aerial Tramway (TR), Bus } \\
\text { (MB), Ferry boat (FB), } \\
\text { Trolleybus (TB), Bus Rapid } \\
\text { Transit (BRT) }\end{array}$ \\
\hline $\begin{array}{l}\text { Nonfixed Guideway (NFG) } \\
\text { "mixed traffic ROW" }\end{array}$ & Not applicable & $\begin{array}{l}\text { Bus (MB), Demand } \\
\text { Response (DR), Jitney (JT), } \\
\text { Publico (PB), Vanpool (VP) }\end{array}$ \\
\hline
\end{tabular}

Source: Authors' typology based on NTD 2004.

Another important consideration for our study is region because we hypothesize that nonunionized labor (prevalent in the South) reduces labor costs. Table 4 represents the regional distribution of population byorganizational form and institutional type and represents the final select sample of 307 agencies. As Tables 2 and 4 demonstrate, utilizing Census Bureau classifications, there is almost an even split between special-purpose governments and general-purpose governments in our sample. 
Table 4. Organizational and Institutional Forms by Regions

\begin{tabular}{|l|l|l|l|l|l|l|}
\hline & \multicolumn{2}{|l|}{ Organizational Form } \\
\hline & $\begin{array}{l}\text { Directly Operated } \\
\text { Services (public } \\
\text { management) }\end{array}$ & \multicolumn{2}{l|}{$\begin{array}{l}\text { Contracting } \text { Out for Some } \\
\text { or All of the Services }\end{array}$} & \multicolumn{2}{|l|}{ Total } \\
\hline Region & $\begin{array}{l}\text { Special- } \\
\text { purpose (1) }\end{array}$ & $\begin{array}{l}\text { General- } \\
\text { purpose (2) }\end{array}$ & $\begin{array}{l}\text { Special- } \\
\text { purpose (3) }\end{array}$ & $\begin{array}{l}\text { General- } \\
\text { purpose (4) }\end{array}$ & N & $\%$ \\
\hline & & & & & & \\
\hline Northeast & 11 & 8 & 19 & 5 & 43 & $14 \%$ \\
\hline Midwest & 20 & 12 & 22 & 30 & 84 & $27 \%$ \\
\hline South & 24 & 38 & 24 & 25 & 111 & $36 \%$ \\
\hline West & 5 & 16 & 29 & 19 & 69 & $22 \%$ \\
\hline & & & & & & \\
\hline Total & 60 & 74 & 94 & 79 & 307 & \\
\hline$\%$ & $20 \%$ & $24 \%$ & $31 \%$ & $26 \%$ & & \\
\hline
\end{tabular}

Source: Authors' calculations from 2004 NTD database.

The resulting population of agencies is not a selected sample, but the universe of interest on which we would like to focus in the following sections of our article. As Table 4 demonstrates, special-purpose governments and general-purpose governments are more or less uniformly distributed across four U.S. Census regions.

\section{Research Design}

The conceptual model represented in Figure 1 is designed to help answer the research question: "All other things being equal, are special-purpose governments more efficient than general-purpose governments in delivering bus services?" We derive this model from the literature review section of this article.

Our model includes several independent variables that measure the level of efficiency of transit operations. The vector of our dependent variables is listed in Table 5. We test several effectiveness indicators to corroborate the results of the efficiency tests. Foster (1997) questions whether special-purpose governments can still be more effective than general- purpose governments even if they may not be as efficient. 


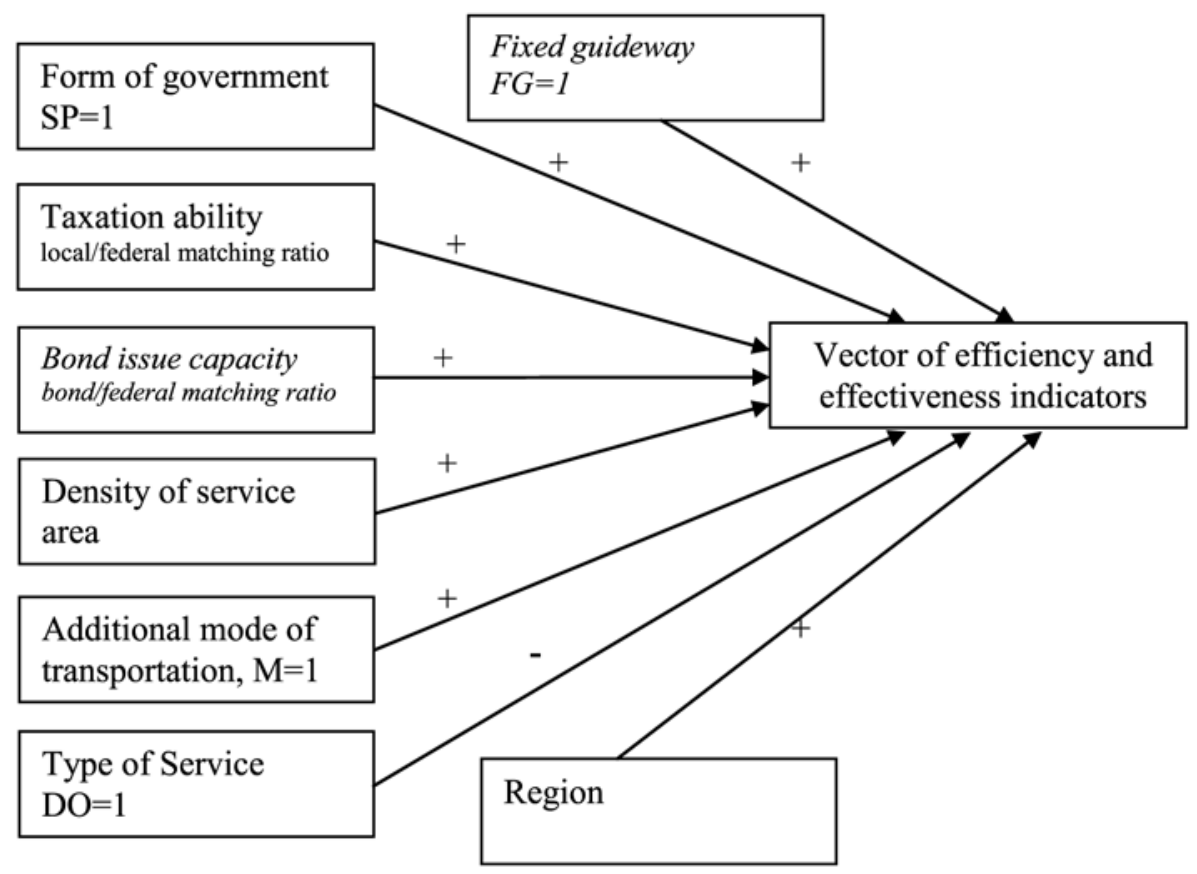

Figure 1. Conceptual Model

The variables indicated in italics are tested, but excluded from the final analysis because of multicollinearity. 


\section{Table 5. Performance Indicators}

\begin{tabular}{|c|c|c|}
\hline $\begin{array}{l}\text { Latent } \\
\text { Concept }\end{array}$ & $\begin{array}{l}\text { Performance } \\
\text { Indicators }\end{array}$ & $\begin{array}{l}\text { Limits to Internal Validity } \\
\text { of the Measurement }\end{array}$ \\
\hline \multicolumn{3}{|c|}{ Efficiency Measures } \\
\hline $\begin{array}{l}\text { I. Labor } \\
\text { productivity }\end{array}$ & $\begin{array}{l}\text { 1. Revenue vehicle mile per } \\
\text { total employee hours } \\
\text { 2. Revenue vehicle hour per } \\
\text { total employee hours }\end{array}$ & $\begin{array}{l}\text { Hours of daily service } \\
\text { Labor work rules } \\
\text { Size of administrative } \\
\text { personnel } \\
\text { Service area network } \\
\text { characteristics }\end{array}$ \\
\hline $\begin{array}{l}\text { II. Service } \\
\text { efficiency }\end{array}$ & $\begin{array}{l}\text { 3. Operating expenses per } \\
\text { revenue vehicle mile } \\
\text { 4. Operating expenses per } \\
\text { revenue vehicle hours }\end{array}$ & $\begin{array}{l}\text { Service area population } \\
\text { characteristics } \\
\text { Service area network } \\
\text { characteristics }\end{array}$ \\
\hline \begin{tabular}{|l} 
III. Cost \\
efficiency
\end{tabular} & $\begin{array}{l}\text { 5. Farebox recovery ratio } \\
\text { 6. Fare revenues per } \\
\text { passenger trip }\end{array}$ & $\begin{array}{l}\text { Fare structure } \\
\text { Hours of daily service } \\
\text { Service area network } \\
\text { structure }\end{array}$ \\
\hline \multicolumn{3}{|c|}{ Effectiveness Measures } \\
\hline $\begin{array}{l}\text { IV.Vehicle } \\
\text { utilization }\end{array}$ & $\begin{array}{l}\text { 7. Revenue vehicle miles } \\
\text { per vehicle operating in } \\
\text { maximum service } \\
\text { 8. Revenue vehicle hours } \\
\text { per vehicle operating in } \\
\text { maximum service }\end{array}$ & $\begin{array}{l}\text { Peak/off peak ratio } \\
\text { Labor work rules } \\
\text { Daily service vehicle/total } \\
\text { fleet ratio } \\
\text { Service area network } \\
\text { characteristics }\end{array}$ \\
\hline $\begin{array}{l}\text { V.Service } \\
\text { effectiveness }\end{array}$ & $\begin{array}{l}\text { 9. Passenger trip per } \\
\text { revenue vehicle hour } \\
\text { 10. Passenger trip per } \\
\text { revenue vehicle mile }\end{array}$ & $\begin{array}{l}\text { Service area population } \\
\text { characteristics } \\
\text { Service area network } \\
\text { characteristics }\end{array}$ \\
\hline $\begin{array}{l}\text { VI.Cost } \\
\text { effectiveness }\end{array}$ & $\begin{array}{l}\text { 11. Operating expense } \\
\text { per passenger mile } \\
\text { 12. Operating expense per } \\
\text { unlinked passenger trip }\end{array}$ & $\begin{array}{l}\text { Service area population } \\
\text { characteristics } \\
\text { Service area network } \\
\text { structure }\end{array}$ \\
\hline
\end{tabular}

Even though we test the same environmental factors against our performance indicators, the presumption is that the explanatory power of each of these indicators will differ from our measures of efficiency and effectiveness. The rationale for using several different performance measures is that these ratios approach efficiency differently. For example, the National Transit Database 2004 Annual 
Report lists two separate indicators for efficiency: operating expense per revenue vehicle mile and operating expense per revenue vehicle hours. Both of these measures attempt to assess inputs (operating expenses) per unit of provided service measured as either revenue vehicle miles (RVM) or revenue vehicle hours (RVH). Both measures have different strengths and weaknesses. While RVM are affected by route structure and road capacity, RVH are impacted by work hours and labor regulations (Fielding, Glauthier, and Lave 1978; Giuliano 1980). Thus, using both measures gives us a more accurate picture of the underlining latent dimensions of service efficiency. Both measures also allow us to test whether special-purpose governments are more efficient because of their geographic flexibility (Hooghe and Marks 2003). We also expect that general-purpose governments will have higher efficiency levels when measured by RVH. Often, RVH-based measures are considered better measures for efficiency indicators (Fielding, Glauthier, and Lave 1978), but our assumption is that RVM are able to capture the geographical dimension of special-purpose governments, which is theoretically important to our study.

As demonstrated in Table 5, there are several important efficiency and effectiveness dimensions that we estimate for bus transit. Service and cost-efficiency measures are supplemented by effectiveness measures because along these dimensions, special-purpose governments may appear to be less efficient, but more effective. It is our notion that the same number of institutional and environmental factors (discussed later in this article) will impact such measures. However, the coefficients and impacts of independent variables could vary from measure to measure.

In this article, we test the following hypothesis: special-purpose governments are more efficient in delivering bus services than general-purpose governments. Therefore, one of our main explanatory variables is the form of government: special-purpose versus general purpose governments. We coded " 1 " if a transit agency is operated by a transit authority or special district and " 0 " if it is operated by the unit of city or county government. We also control for regional differences and include a dummy variable that equals " 1 " if a transit agency is situated in the South, and " 0 " for all other regions. As noted before, Southern agencies may have lower labor costs because of state right-to-work laws and the absence of unions.

The next control variable that we test is population density of the service area. We use the population served over the area served for each transit agency as a measure of whether the service area is more sparsely populated or more compact. 
We assert that the denser the population, the more efficient service areas become due to heavier usage and shorter trips.

We employ a dummy variable to control whether a system contains a fixed guideway. A fixed guideway is "a mass transportation facility using and occupying a separate right-of-way or rail for the exclusive use of mass transportation and other high occupancy vehicles; or using a fixed centenary system useable by other forms of transportation" (National Transit Database 2004). Here, our assumption is that such systems are more capital intensive and have higher operational costs. Besides controlling for FGs as a more capital-intensive service, we also control for whether an agency operates another mode of transportation in addition to buses.

An important component in determining whether an agency receives federal funding is its ability to match dollar-for-dollar with local revenue (Smirnova, Leland, and Johnson 2005). For this reason, we include several measures to capture the federal matching capacity of a transit agency. First, we hypothesize that having a higher ratio of local to federal funding will be positively correlated with our efficiency indicators, particularly cost and service efficiency, because this tax ratio indicates the transit agency's ability to match funds. Another way a transit agency can raise matching funds is through issuing bonds. To control for this, we include a ratio of the amount expended on bond payments in fiscal year 2004 to the federal funding acquired during 2004. Finally, we control for the type of service provided by a transit agency.

The following equation paraphrases our model in general form:

$$
Y_{i}=\alpha+\beta_{1 i} S P_{i}+\beta_{2 i} B_{i}+\beta_{3 i} T_{i}+\beta_{4 i} D_{i}+\beta_{5 i} M_{i}+\beta_{6 i} F G_{i}+\beta_{7 i} D O+\beta_{7 i} R_{i}+\varepsilon_{i}
$$

where:

Y represents our vector of dependent variables which measures different aspects of efficiency and effectiveness, such as the farebox recovery ratio

$S P_{i} \quad$ is a dummy variable that equals " 1 " if a transit agency is a special-purpose government

$B_{i} \quad$ is a dummy variable representing whether an agency paid bond interest during the fiscal year

$T_{i} \quad$ represents the ratio of local funding to federal funding

$D_{i} \quad$ is the density of the service area 
Table 6. One-Way ANOVA Results

\begin{tabular}{|c|c|c|}
\hline Latent Concept & Performance Indicators & $\begin{array}{l}\text { ANOVA } \\
\text { Significance } \\
\text { Results }\end{array}$ \\
\hline $\begin{array}{l}\text { I. Vehicle } \\
\text { utilization }\end{array}$ & $\begin{array}{l}\text { 1. RVM per vehicle operating in } \\
\text { maximum service (RVM/VOMS) } \\
\text { 2. RVH per vehicle operating in } \\
\text { maximum service (RVH/VOMS) }\end{array}$ & $\begin{array}{l}0.058 \\
0.304\end{array}$ \\
\hline $\begin{array}{l}\text { II. Labor } \\
\text { productivity }\end{array}$ & $\begin{array}{l}\text { 3. } \text { RVM per total employee } \\
\text { hours (RVM/TEH) } \\
\text { 4. RVM per total employee } \\
\text { hours(RVH/TEH) }\end{array}$ & $\begin{array}{l}0.003 * * \\
0.022^{*}\end{array}$ \\
\hline $\begin{array}{l}\text { III. Service } \\
\text { efficiency }\end{array}$ & $\begin{array}{ll}\text { 5. Operating expenses per } \\
\text { RVM (OPEX/RVM) } \\
\text { 6. Operating expenses per } \\
\text { RVH (OPEX/RVH) }\end{array}$ & $\begin{array}{l}0.006^{* *} \\
0.039^{*}\end{array}$ \\
\hline $\begin{array}{l}\text { Service } \\
\text { effectiveness }\end{array}$ & $\begin{array}{ll}\text { 7. } & \text { Passenger trip per RVH } \\
\text { (PASST/RVH) } \\
\text { 8. } \begin{array}{l}\text { Passenger trip per RVM } \\
\text { (PASST/RVM) }\end{array}\end{array}$ & $\begin{array}{l}0.088^{*} \\
0.078^{*}\end{array}$ \\
\hline $\begin{array}{l}\text { IV. Cost } \\
\text { efficiency }\end{array}$ & $\begin{array}{l}\text { 9. Farebox recovery ratio } \\
\text { (Fare/OPEX) } \\
\text { 10. Fare revenues per passenger trip } \\
\text { (Fare/PASST) }\end{array}$ & $\begin{array}{l}0.002^{* *} \\
0.937\end{array}$ \\
\hline $\begin{array}{l}\text { Cost } \\
\text { effectiveness }\end{array}$ & $\begin{array}{l}\text { 11. Operating expense per passenger } \\
\text { mile (OPEX/PASSM) } \\
\text { 12. Operating expense per unlinked } \\
\text { passenger trip (OPEX/PASST) }\end{array}$ & $\begin{array}{l}0.303 \\
0.382\end{array}$ \\
\hline
\end{tabular}

Notes: The results represented are based on two-tailed test of significance, using one-way ANOVA function in SPSS 13.0 program.

${ }^{*} \mathrm{p}<0.05 ;{ }^{* *} \mathrm{p}<0.01$

$M_{i} \quad$ is another dummy variable that stands for whether the transit agency operates an additional mode of transportation

$F G_{i}$ is a dummy variable that represents whether the agency's bus system operates on a fixed guideway

$D O_{i}$ stands for agencies that directly operate all of their services

$R_{i} \quad$ is a regional variable, where $1=$ the South, and all other regions are 0 s. 


\section{Results}

The results of various tests performed to estimate our model are discussed in this section. ${ }^{2}$

We use several different tests to triangulate the information derived from our data. Since our dataset contains several dependent variables, the first test that we perform is a one-way ANOVA test. This test allows us to compare the means of several variables with respect to certain categorical variables, in our case, specialpurpose versus general-purpose governments.

Labor productivity, service efficiency, and farebox recovery ratios are significant for all measures, with $\mathrm{p}<0.001$ and 0.05 . In addition, vehicle utilization (RVM/ VOMS) and both of the service effectiveness variables have marginal significance levels of $p<0.10$. The results are presented in Table 6 . Cost effectiveness indictors and fare revenues per passenger trip measures were not significant.

The results of this test are triangulated with a t-test, which treats special-purpose and general-purpose governments as two separate groups and assumes unequal variances. The $t$-test gives essentially the same results as one-way ANOVA. Oneway ANOVA, while robust, is a simple test of the difference in means that does not control for the various exogenous factors. The only conclusion that we can reach with such tests is that special-purpose and general-purpose governments perform differently on the set of efficiency and effectiveness measures listed in Table 5, but we cannot tell whether special purpose or general purpose are more efficient and/or effective. For this reason, we employ multiple regression to test our model directly. Multicollinearity tests indicate that controlling for fixed guideways and bond ratios represent a major challenge in producing coefficient estimates that are efficient and unbiased. Fixed guideway is highly correlated with mode and the form of government variables. The variable for issued bonds is highly correlated with the form of government and tax-matching ratio. Thus, we run the tests that both include and exclude them. The results were more or less stable with the unstandardized regression coefficients changing within standard errors from model to model (Berry and Feldman 1985). We delete both of these variables from the final model.

We use the following equation for our final model:

$$
Y_{i}=\alpha+\beta_{1 i} S P_{i}+\beta_{2 i} T_{i}+\beta_{3 i} D_{i}+\beta_{4 i} M_{i}+\beta_{5 i} D O+\beta_{6 i} R_{i}+\varepsilon_{i}
$$

The results of our statistical analysis are reported in Table 7. ${ }^{3}$ The table is organized by efficiency and effectiveness measures similar to Table 5 . For different 


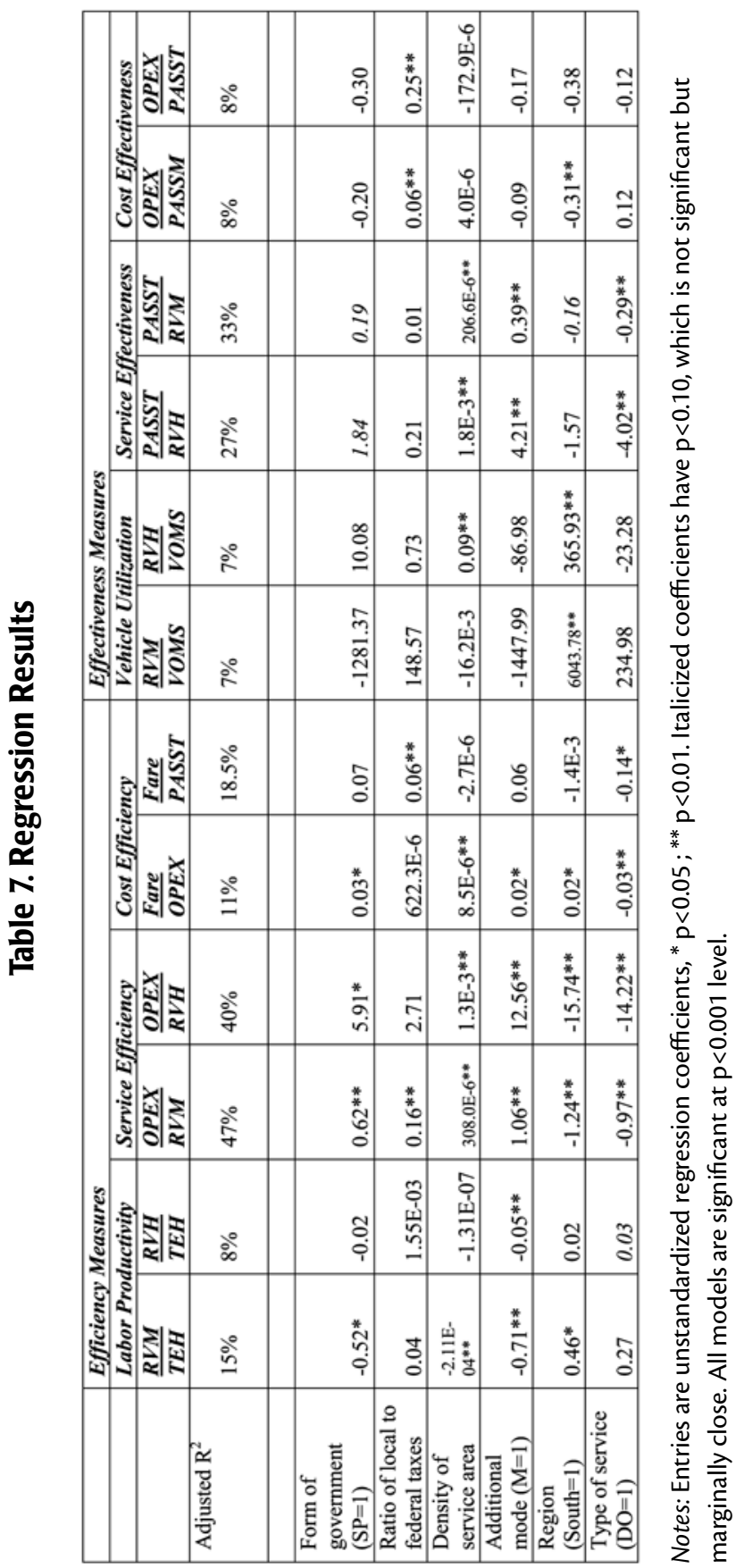


performance indicators, our model predicts from about 7 to 47 percent of the total variance at a statistically significant level $(p<0.001)$. The form of government matters for labor productivity when measured by RVM. In fact, special-purpose governments are less efficient than general-purpose governments in this respect. However, we note that Giuliano (1980) had similar results for special-purpose governments. She determined that this could be a result of general-purpose governments underestimating their total employee hours because of shared personnel with the other departments.

The other efficiency indicator for which form of government matters is service efficiency measured by RVM and farebox recovery ratios. Special-purpose governments have larger farebox recovery ratios and spend more per RVM than generalpurpose governments. This is likely attributed to the fact that special-purpose governments have different fare structures and different network structures than general-purpose governments. They also typically have different financing structures. In addition, general-purpose governments tend to underreport costs in areas such as personnel, where functions are shared among different departments. Therefore, general-purpose governments' operating expenses may appear more efficient than they actually are because the true costs are not fully disclosed (Fielding, Glauthier, Lave 1978). Another variable that supports a difference in network structure is service effectiveness measured by RVM.

Service area density is significant in almost all of our models, but it is a very small value. By far the most interesting finding is the influence of additional modes of transportation and the type of service provided. If a special-purpose government transit agency has to operate an additional mode of transportation, then it has both higher service efficiency and effectiveness levels. It also has a higher farebox recovery ratio, but lower labor productivity. This could indicate that such an agency would have high farebox revenues from both modes of transportation and a larger labor force to serve both of these modes. At the same time, there could be certain economies of scope in performing several modes of transportation under the same agency. We think this is an area worth researching, but it is beyond the scope of this particular research design, which focuses only on bus service.

Transit agencies that directly operate services are less effective and less cost efficient, but have higher levels of service efficiency than those agencies that contract out services. These three sets of measures are reported in the National Transit Database's annual publication for 2004 (National Transit Database 2004). This 
finding indicates that there are certain performance advantages in contracting out transit services, and is an interesting topic for future research.

\section{Discussion}

We assert that the boundaries citizens draw when they create special-purpose governments or city or county governments matter in American politics. Boundaries define the limits of particular arrangements of political power, types and levels of service delivery, ability to secure dedicated funding, characteristics of political participation, and accountability and certain arrangements for funding the work of the local government. For this study in particular, we argue that institutional arrangements for transit districts make a difference in the level of efficiency and effectiveness in administering public bus service. As public transit becomes more and more important to our economy and budgetary resources continue to be scarce, we need to better understand which type of governing system achieves optimal efficiency.

While controlling for federal funding, contracting out, region, population density, additional modes of transportation, and region, we find that special-purpose governments are more likely than general-purpose governments (cities and counties) to have a higher farebox recovery ratio than general-purpose governments as well as high service effectiveness as measured by RVM. At the same time, they have lower labor productivity and service efficiency than general-purpose governments. This finding could be the result of transit agencies housed in general-purpose governments underestimating their true labor costs by not reporting labor expenses shared with other departments. When these efficiency and effectiveness indicators are measured by RVH, there is no statistically significant difference between special-purpose and general-purpose governments. One likely explanation for this is that RVM are more sensitive and representative of the network structure operated by an agency and thus these measures capture the geographic flexibility of special-purpose governments.

Perry and Babitsky (1986) found that special-purpose governments stand out as more effective in generating revenues than general-purpose governments using data from more than 20 years ago. This also could explain why, for the other efficiency and effectiveness indicators, our major explanatory variable was not statistically significant. In effect, we control for the major factor that we think leads to increased efficiency in public transit, which is the ability of special-purpose 
governments to raise additional funds through local taxes. In fact, this variable significantly increases the cost effectiveness of transit agencies.

We also discover that governments that contract out for some or all of their services are also more efficient, except in terms of service efficiency, than those public agencies that directly operate all of their services. When a service is something that can easily be quantified and monitored, contracting out for some or all bus services can maximize efficiency. This is counter to the findings of Perry and Babitsky (1986) that contract-managed systems operate no more efficiently than publicly managed systems. We believe the difference between our findings and theirs on this variable is due to three factors: (1) the data utilized in their study are considerably older and contains half the number of transit agencies utilized in this study; (2) the world of contracting may have become more sophisticated, relying less on fixed-cost or percentage of revenue contracts that provide few incentives for efficiency; and (3) they did not use farebox recovery ratios as an efficiency measure, instead they focused on revenue generation for operating expenses and exclude capital expenses. This has important implications for transit administrators, elected officials, and citizens involved in bus service delivery. However, it is important to note that our results cannot be generalized to other areas of public transit such as light or heavy rail or purely privatized bus systems.

\section{Conclusion}

Our empirical results support the viewpoint that organization form is related to the efficiency of bus service delivery. Future research could include multiple years of data to determine if efficiency varies over time. This poses a considerable challenge to researchers because NTD reporting requirements have not been uniform over the past 24 years. A second area for future research would be to analyze the variables that specifically relate to the different types of governance systems (such as whether boards are elected or appointed), and measure their influence on a larger set of efficiency and effectiveness indicators. Both of these areas should be investigated to better inform transit policymaking.

\section{Endnotes}

${ }^{1}$ Modern-day public bus systems are largely public, and only a small percentage are privatized. Because the goals of private systems may be radically different 
from publicly owned and managed systems, we choose to exclude them from our research.

${ }^{2}$ The preliminary tests run on the model indicate that operating a fixed guideway for bus services is highly correlated with operating additional modes of transportation as well as the form of government. At the same time, bond ratios are also highly correlated to the ratio of matching funds and form of government. For this reason, we excluded these variables to avoid multicollinearity (Fox 1991). This is also consistent with the literature on special-purpose governments (Sbragia 1996).

${ }^{3}$ Careful examination of our data has led us to exclude three agencies that have very few passenger trips and passenger miles compared to their operating expenses. These agencies also have very low farebox revenues when compared to the other agencies, and are supported by a higher proportion of local taxes than the rest of the agencies studied. We exclude these extreme cases, based on Cook's $D$ measures. The final regression results reported do not include these cases. However, the regression results are not different if we leave the cases in, for all performance indicators but cost-effectiveness measures.

\section{References}

Berry, William, and Stanley Feldman. 1985. Multiple regression in practice. Sage Publication Series Quantitative Applications in Social Sciences 50.

Bureau of Transportation Statistics (BTS). 2002. Source and accuracy compendium: National Transit Database (NTD) and Safety Management Information System (SAMIS). Available online at http://www.bts.gov/programs/ statistical_policy_and_research/source_and_accuracy_compendium/FTA_ national_transit.html. Last accessed October 2007.

Burns, Nancy. 1994. The formation of American local governments: Private values in public institutions. Oxford University Press.

Eger, Robert. 2002. Casting light on shadow government: An exploratory analysis of public authorities in the southern states. Paper presented at the Association for Budgeting and Financial Management, Washington, DC, January 1719, 2002. Available online at http://www.abfm.org/pdf_2001_conf/eger2.pdf.

Fielding, Gordon, Roy Glauthier, and Charles Lave. 1978. Performance indicators for transit management. Transportation 7: 365-379. 
Foster, Kathryn. 1997. The political economy of special purpose government. Washington, DC: Georgetown University Press, pp. 260.

Fox, John. 1991. Regression diagnostics. Sage Publication Series Quantitative Applications in Social Sciences 79.

Giuliano, Genevieve Mary. 1980. Transit performance: The effect of environmental factors. PhD diss., University of California, Irvine.

Hooghe, Liesbet, and Gary Marks. 2003. Unraveling the central state, but

how? Types of multi-level governance. American Political Science Review 97, 2 p: 223-241.

The National Transit Database. 2004. The 2004 reporting manual. Available online at http://www.ntdprogram.com/ntdprogram/pubs/ARM/2004/2004ARM. htm. Last accessed October 21, 2006.

Olberding, Julie. 2002. Does regionalism beget regionalism? The relationship between norms and regional partnerships for economic development. Public Administration Review 62, 4 (July/August).

Perry, James, and Timlynn Babitsky. 1986. Comparative performance in urban bus transit: Assessing privatization strategies. Public Administration Review. January/February: 57-66.

Sbragia, Alberta. 1996. Debt wish: Entrepreneurial cities, U.S. federalism, and economic development. The University of Pittsburg Press.

Smirnova, Olga, Suzanne Leland, and Gary A. Johnson. 2005. Are special purpose governments financially advantaged? An empirical study of federal funding of transit districts. Paper presented at the Annual Association of Public Policy and Management meetings. Washington DC.

\section{About the Authors}

SUZANNE LeLAND (smleland@uncc.edu) is an associate professor in the political science department at the University of North Carolina at Charlotte, where she teaches state and local politics, urban politics, and intergovernmental relations. She has published articles in Public Administration Review and Public Administration Quarterly. She is also the co-editor of Case Studies of City-County Consolidation: Reshaping the Local Government Landscape with Kurt Thurmaier. 
Olga SMIRnOVA (ovsmirno@uncc.edu) is a Ph.D. student in the final stages of the public policy program at the University of North Carolina at Charlotte. Her research interests include public transportation performance, efficiency and effectiveness analysis, policy analysis, migration, special-purpose governments, public transit, and annexation. Her dissertation topic is "Does Government Structure Really Matter? A Comparison of Efficiency and Effectiveness of Special Purpose versus General Purpose Government Transit Operations." 